\title{
The involvement of a South African church in a changing society
}

\begin{abstract}
Author:
Willem J. Schoeman ${ }^{1}$

Affiliation:

${ }^{1}$ Department of Practical

Theology, University of the

Free State, South Africa

Correspondence to:

Kobus Schoeman

Email:

schoemanw@ufs.ac.za

Postal address:

Internal Box 93, PO Box 339,

Bloemfontein 9300,

South Africa

Dates:

Received: 08 Mar. 2012

Accepted: 04 Sept. 2012

Published: 22 Oct. 2012

How to cite this article: Schoeman, W.J., 2012, 'The involvement of a South African church in a changing society', Verbum et Ecclesia 33(1), Art. \#727, 8 pages. http://dx.doi.org/10.4102/ ve.v33i1.727

Note:

Part of this article was delivered by the author as a paper ('The involvement of a South African church in a changing society') at the ISSR conference on 27-31 July 2009 in Santiago de Compostela, Spain.
\end{abstract}

C 2012. The Authors. Licensee: AOSIS OpenJournals. This work is licensed under the Creative Commons Attribution License.
The church and its congregations are an important part of society. The aim of this article was to provide a description of the involvement of the Dutch Reformed Church (DRC) in a changing society. A short description of the changes in the South African society over the last 15-20 years was provided. The role and response of churches was then considered, and lastly, there was a more in-depth discussion on the involvement of the DRC, its leadership and its congregations in society. The argument of this article was that there is a movement towards less involvement in society by the DRC. The involvement of congregations is mostly on the level of welfare projects within an evangelist approach. It was argued that the challenge for congregations is to build partnerships of trust within their communities for the purpose of sustainable people development.

\section{Introduction}

The aim of this article is to provide a description of the involvement of a specific church, the Dutch Reformed Church (DRC), in a changing society, namely, the South African society. First of all, the article presents a short description of the changes in the South African society over the last 15-20 years. Then it considers the role and response of churches during this time and lastly, it presents an in-depth discussion of the involvement of the DRC, its leadership, and its congregations in the South African society and its different communities.

The church and its congregations are an important part of society. The interaction between congregation and community cannot be overlooked in the search to describe the involvement of the church in a changing society. Congregations have the calling to serve society; the missio Dei becomes the missiones ecclesiae (Bosch 1991:370, see also Bosch 1991:378-381; Van Gelder 2007:41-46). Hendriks (2007:1000) says, 'We believe theology is contextual and missional by its very nature and that it should address society's issues and problems in a holistic way'. The critical question is: Do churches and congregations make a difference in society? Or to be more specific: To what extend do the DRC and its congregations make a difference in the South African society?

\section{South African churches in a changing environment}

South African society has experienced an enormous amount of change during the last two decades; it can correctly be called a society in transition. The transformation from an apartheid society to a democratic society was dramatic and radical. The entire political order changed from a minority government to an open and democratic society with all its citizens participating. This transition was not only about political transformation, but it led to the opening up of the South African society to the world and influences such as globalisation and world trends. A new democratic and human-rights culture replaced a closed and privileged society that benefited only a few. Within years, South Africa became part of a 'flat world' (Friedman 2006:5), with all its consequences.

The church community and its members could not escape from these changes. It is clear that churches are now operating in a cultural and socio-political environment very different from the one before 1990. These changes in the South African context are having far-reaching consequences for the role and involvement of churches in society. The playing field has changed and therefore the critical question is: How is this impacting the church?

In the past, the different churches in South Africa were not involved in society in similar ways, and neither are they today. On the one hand, in the old South Africa, some churches were part of the liberation struggle. The relationship between church and State (1960-1990) in these churches could be understood as one of resistance (Kumalo \& Dziva 2008:172). The 'resistance' churches were opposed to the apartheid regime and were in favour of the transformation of society. On the other hand, the 'White' Reformed churches were not in favour of the radical transformation of 
the South African society. To a large extent, they associated with and supported the status quo. The advent of the new South Africa changed the position of all churches and their involvement in society.

After 1990, the years of struggle and resistance were gone, and the new political situation required a new involvement of the church in society. The church had to look for a new way forward and an appropriate theology for the ministry in the new socio-political and economic context (Kumalo \& Dziva 2008:174).

According to Kumalo and Dziva (2008):

There is a sense in which the church has grown tired of struggling. Most church leaders would like to move out of the public arena and limit their ministry to activities such as preaching, counselling and visitation. (p. 181)

This is mostly true for churches that were on the 'resistance' side of the spectrum.

In the resistance churches before 1994, Christian witness was concerned with the end of apartheid, but the ability to engage with the wider socio-economic and cultural themes of the new nation was lacking (De Gruchy \& Ellis 2008:9). The shift that was now required by the churches was one from resistance to assistance, from being contrary to being in favour. There is a difference between the tools required in breaking down and those required in building up (De Gruchy \& Ellis 2008:11). Religious organisations were once the voices of poor people. 'However, since 1994, with a few notable exceptions, they have lapsed into their comfort zones and are preoccupied exclusively with the after-life' (Dinokeng n.d.:18).

A complex situation such as post-apartheid South Africa cannot be described in a few sentences, but the main argument is that churches cannot escape the changes within the new South African society. The focus of this article will now shift from the broader perspective to a specific perspective, namely, on one of the South African churches, the DRC. How did the socio-political changes in South Africa influence the DRC, especially congregations of this church at ground level?

\section{The Dutch Reformed Church in a society in transition}

Before 1990, the DRC was on the opposing side of the 'resistance'. The DRC is a mainly 'White' Reformed church and had a very close relationship with the State before 1990. In the 1930s and 1940s, the DRC, through its diaconal ministry, played an important role in alleviating the 'poor white problem' (Erasmus 2009:47; see also Kritzinger 1994). According to De Gruchy and Elllis (2008):

The Church threw itself into meeting the social and developmental needs of its members with huge and commendable effort, developing a wide range of diaconal programmes. The tragedy was that its racist ideology prevented it from meeting the needs of all God's people, and so it ultimately played into the hands of apartheid politicians. (p. 12)
Before 1990, the DRC was to a large extent primarily involved in the 'White' community (Erasmus, Louw \& Van der Merwe 2009:17).

The DRC, as is the case with all South African churches, cannot bypass the changes in the new South African society (see Durand 2002). The critical question is: To what extent is the DRC, its members and its congregations involved in society today? What tools are they using to build up the South African society and the different communities of which they form part?, The aim of this article is to answer these questions as part of the descriptive-empirical task of practical theology by looking at empirical research (see Osmer 2008:31ff.) that has been done in the DRC in this regard.

A comprehensive quantitative survey (called Church Mirror) was conducted in the DRC in 2006. The involvement of congregations and their leadership in society was one of the aspects researched in the survey. The survey was conducted using three research groups within the DRC. Different questionnaires were sent to the following three groups:

- Congregations. There are 1176 congregations in the DRC. A questionnaire was sent to every congregation, and $52 \%$ (602) of the congregations returned a completed questionnaire. In some instances, the results are compared with previous surveys done in 2000 and 2004.

- Leaders (in this instance: elders, deacons, and smallgroup leaders). A stratified random sample of $15 \%$ of congregations in every regional synod was selected. Of the congregations surveyed, $77 \%$ returned 2342 questionnaires completed by the leadership of those congregations.

- Attendees of a worship service. A random sample of $10 \%$ was selected from all congregations. From all possible congregations, 118 were selected and asked to complete the questionnaire during August 2006. In this case, 81\% (95) of the congregations returned 12522 questionnaires completed by worshippers. The questionnaire is the same that was used in the National Church Life Surveys (NSLS) (see Woolever \& Bruce 2004). In calculating the scores, the Presbyterian Church's (PC[USA]) methodology was used.

Findings from all three of these research groups will be used to provide a descriptive-empirical picture of the involvement of the DRC in society. This picture focuses on the mid-2000s, but it must be seen against the broader background of the changing South African society.

\section{The involvement of congregations in their communities}

Congregations are located within a particular community and are therefore part of a community. The question is: What do congregations do in their communities? Congregations reported an increased involvement in development projects between 2004 and 2006 (Table 1). More than two thirds of the congregations are involved in some kind of project to perform development work in the community. What is the nature of these projects (Table 2)? Most of these projects are feeding projects, in other words, providing food to the hungry. The next notable project is training classes. These 
are mostly classes that train domestic workers to perform needle and sewing work. Who takes responsibility for these projects or programmes (Table 3)? In the majority of cases, individual members of the congregation are engaged with these projects. Secondly, commissions or committees of the congregation are responsible for community work.

People who are living with HIV or AIDS and poverty are two of the greatest challenges in the South African society, '... about $40 \%$ of households still live below the poverty line' (Dinokeng n.d.:25) and South Africa has '... the fourth highest rate of infection of HIV / Aids in the world' (Dinokeng n.d.:30). To a certain extent, no community is isolated from the effects of these two problems. It could therefore be expected that congregations are in some way involved in a strategy or project to alleviate the effects of HIV or AIDS, or poverty. In the case of the DRC, only $10 \%$ of congregations are working according to an HIV or AIDS, or poverty and employment strategy (Table 4 and Table 6). In the case of people living with HIV or AIDS, congregations are mostly involved with community projects outside of the congregation (Table 5), whilst with regard to poverty and employment they are mostly involved in their own strategy or project (Table 7).

Congregations are involved in their communities, but it is mostly through feeding projects. By means of formal strategies and structures, individual members are more involved than congregations. People living with HIV or AIDS, and poverty are not the main focus of congregations in community involvement.

\section{The involvement of leaders and members of the congregation in their community}

What are individuals, leaders or members of the congregation doing in the community? It has already been stated above that individuals are playing an important role in the involvement of congregations. Individual involvement can be described in two ways:

- One way of being involved in a community is by serving that specific community. This could be means of doing charitable work in the community, such as donating money, attending to the sick and poor, or being part of projects and programmes that are doing community work.

- Another way of being involved in the community is by inviting nonmembers from the community to become involved with the congregation and its activities. This could be done by motivating members to tell others about their faith and, for example, by inviting others to attend a worship service.

Both these aspects of community involvement will now be discussed.

\section{Serving the community}

Nearly a third of churchgoers and half of the leaders are involved in a form of community service through groups outside of the congregation (Table 8 and Table 9).
TABLE 1: Does the congregation undertake community development projects?

\begin{tabular}{lcc}
\hline Response & \multicolumn{2}{c}{ Year } \\
\cline { 2 - 3 } & $\mathbf{2 0 0 4}$ & $\mathbf{2 0 0 6}$ \\
\hline Yes & 63 & 70 \\
No & 28 & 25 \\
None & 9 & 5 \\
\hline
\end{tabular}

Responses are given in percentage. This data was obtained from the congregational survey.

TABLE 2: If yes, which of the following projects does your congregation undertake?

\begin{tabular}{|c|c|c|c|c|c|c|}
\hline \multirow[t]{3}{*}{ Projects undertaken } & \multicolumn{6}{|c|}{ Year } \\
\hline & \multicolumn{3}{|c|}{2004} & \multicolumn{3}{|c|}{2006} \\
\hline & Yes & No & None & Yes & No & None \\
\hline Feeding projects & 63 & 5 & 31 & 65 & 3 & 31 \\
\hline Housing projects & 6 & 26 & 68 & 4 & 19 & 76 \\
\hline Guidance programmes & 15 & 21 & 65 & 13 & 15 & 72 \\
\hline Literacy classes & 13 & 22 & 66 & 12 & 17 & 71 \\
\hline Working classes & 25 & 17 & 58 & 21 & 14 & 65 \\
\hline $\begin{array}{l}\text { Other projects or } \\
\text { programmes }\end{array}$ & 33 & 12 & 56 & 36 & 8 & 56 \\
\hline
\end{tabular}

Responses are given in percentage. This data was obtained from the congregational survey.

TABLE 3: Who takes responsibility for the projects or programmes?

\begin{tabular}{|c|c|c|c|c|c|c|}
\hline \multirow[t]{3}{*}{ Responsible party } & \multicolumn{6}{|c|}{ Year } \\
\hline & \multicolumn{3}{|c|}{2004} & \multicolumn{3}{|c|}{2006} \\
\hline & Yes & No & None & Yes & No & None \\
\hline Women's committee & 27 & 13 & 60 & 27 & 8 & 65 \\
\hline Church council & 29 & 10 & 60 & 29 & 7 & 64 \\
\hline Commissions & 38 & 8 & 54 & 40 & 6 & 54 \\
\hline Youth groups & 10 & 18 & 73 & 13 & 11 & 76 \\
\hline $\begin{array}{l}\text { Members of the } \\
\text { congregation }\end{array}$ & 56 & 4 & 40 & 58 & 2 & 40 \\
\hline
\end{tabular}

Responses are given in percentage. This data was obtained from the congregational survey.

TABLE 4: Do you plan in the congregation according to a community-based strategy for people living with HIV or AIDS?

\begin{tabular}{lccc}
\hline Response & \multicolumn{3}{c}{ Year } \\
\cline { 2 - 4 } & $\mathbf{2 0 0 0}$ & $\mathbf{2 0 0 4}$ & $\mathbf{2 0 0 6}$ \\
\hline Yes & 3 & 12 & 10 \\
No & 97 & 88 & 90 \\
\hline
\end{tabular}

Responses are given in percentage. This data was obtained from the congregational survey.

TABLE 5: Strategy for people living with HIV or AIDS: If yes, give a short description of the strategy.

\begin{tabular}{ll}
\hline Description & $\mathbf{\%}$ \\
\hline No description & 90 \\
Involved with projects outside the congregation in the community & 7 \\
Own strategy or projects & 3 \\
\hline Responses are given in percentage. This data was obtained from the congregational survey.
\end{tabular}

Responses are given in percentage. This data was obtained from the congregational survey.

TABLE 6: Is there a poverty- and employment-strategy implemented in the congregation?

\begin{tabular}{lcc}
\hline Response & \multicolumn{2}{c}{ Year } \\
\cline { 2 - 3 } & $\mathbf{2 0 0 4}$ & $\mathbf{2 0 0 6}$ \\
\hline Yes & 12 & 10 \\
No & 88 & 90 \\
\hline
\end{tabular}

Responses are given in percentage. This data was obtained from the congregational survey.

TABLE 7: Poverty- and employment-strategy: If yes, give a short description of the strategy.

\begin{tabular}{ll}
\hline Strategy & $\%$ \\
\hline No description & 74 \\
Involved with projects outside the congregation in the community & 7 \\
Own strategy or projects & 11 \\
Christian social services (CMR) & 7 \\
Busy developing own strategy & 1 \\
\hline
\end{tabular}

This data was obtained from the congregational survey. 
Most members of both groups (leaders and attendees) are prepared to donate food or prepare food for someone outside of their family. Most of these activities are ad hoc activities, for example, loaning or donating money, caring for the sick or voting in an election. The lowest response for both the attendees and leaders are in co-operating with others to solve a community problem. This will probably require a more intense or longer-term commitment. It is also interesting to note that more leaders than attendees are prepared to become involved in community service and in activities servicing the community.

\section{Reaching out to nonmembers}

Nonmembers can be reached by motivating attendees to talk about their faith to others and by inviting them to their congregation:

- Talking about faith (Table 10). A great majority of attendees $(70 \%)$ and leaders (73\%) feel mostly at ease talking about their faith and do so if the opportunity arises. At the same time, both groups do not actively seek opportunities to do so.

- Inviting others (Table 11). In the last 12 months, more than half of the attendees and nearly two thirds of the leaders have invited a friend or relative (that is not a member of a congregation) to a worship service. Most of the rest have done so, but not in the last twelve months. There is openness towards inviting others to their congregation.

Leaders and attendees are talking about their faith and are inviting others. A critical question is: Are they inviting everybody in the community or are they only inviting persons that will be acceptable in the particular attendees congregation? In other words, is this an open or selective process?

\section{Comparing the Dutch Reformed Church's community connections}

By serving the community and reaching out to nonmembers, a description of the connection between congregation and community is given. This connection with the community can be compared with that of other congregations to assist in better understanding the community connections of DRC congregations. Concerning community connections, the DRC's scores are therefore compared to those of the Presbyterian Church (PC [USA]). This is only used as a point of reference and to help with understanding the phenomenon. The comparison can surely be criticised. The following three aspects of connections with communities are discussed for the purposes of the comparison:

- Focusing on the community (Table 12). The DRC scores lower in most respects. The exception is the congregation's emphasis on community care and social justice (D). However, DRC attendees report a lower involvement in the community.

- Sharing faith (Table 13). Attendees are prepared to invite a friend or relative to a worship service (C), but they are not much involved in evangelistic activities. To invite somebody they know is easier than being involved in evangelistic activities.
TABLE 8: Are you involved in any community service through groups outside the congregation?

\begin{tabular}{lll}
\hline Response & Attendees & Leaders \\
\hline Yes & 30 & 44 \\
No & 70 & 56 \\
\hline
\end{tabular}

Responses are given in percentage. This data was obtained from the attendees and leader surveys.

TABLE 9: In the past 12 months, have you done any of the following? (Mark all that apply).

\begin{tabular}{lll}
\hline Actions & Attendees & Leaders \\
\hline $\begin{array}{l}\text { Loaned money to someone outside your family } \\
\begin{array}{l}\text { Cared for someone outside your family that was } \\
\text { very sick }\end{array}\end{array}$ & 38 & 42 \\
$\begin{array}{l}\text { Donated or prepared food for someone outside } \\
\text { your family }\end{array}$ & 56 & 38 \\
$\begin{array}{l}\text { Voted in the last election } \\
\text { (national or local) }\end{array}$ & 63 & 65 \\
$\begin{array}{l}\text { Donated money to a charitable organisation } \\
\text { (other than this congregation) }\end{array}$ & 52 & 65 \\
$\begin{array}{l}\text { Worked with others to try to solve a community } \\
\text { problem }\end{array}$ & 17 & 32 \\
\hline
\end{tabular}

Responses are given in percentage. This data was obtained from the attendees and leader surveys.

TABLE 10: Which of the following best describes your readiness to talk to others about your faith?

\begin{tabular}{lll}
\hline Readiness & Attendees & Leaders \\
\hline I do not have faith, so the question is not applicable & 0 & 0 \\
$\begin{array}{l}\text { I do not talk about my faith; my life and actions are } \\
\text { sufficient }\end{array}$ & 8 & 4 \\
$\begin{array}{l}\text { I find it hard to talk about my faith } \\
\begin{array}{l}\text { I mostly feel at ease talking about my faith and do } \\
\text { so if it comes up }\end{array}\end{array}$ & 70 & 7 \\
$\begin{array}{l}\text { I feel at ease talking about my faith and seek } \\
\text { opportunities to do so }\end{array}$ & 12 & 73 \\
\hline
\end{tabular}

Responses are given in percentage. This data was obtained from the attendees and leader surveys.

TABLE 11: Have you invited to a worship service here any of your friends or relatives who do not now attend a congregation?

\begin{tabular}{lll}
\hline Invitation & Attendees & Leaders \\
\hline Yes, I have done it in the last 12 months & 53 & 63 \\
Yes, but I haven't done it in the last 12 months & 40 & 34 \\
Don't know & 4 & 2 \\
No, but would not do it & 2 & 1 \\
No, definitely not & 0 & 0 \\
\hline
\end{tabular}

Responses are given in percentage. This data was obtained from the attendees and leader surveys.

- Welcoming new worshippers (Table 14). A congregation grows by welcoming new worshippers. Here, the figures for the DRC are slightly higher. However, are those being welcomed 'new' worshippers or only DRC members from other congregations?

In summary, the external connections of the two denominations can be compared (Table 15). This table gives a summary of the external connection indexes of the survey. In the DRC, the external connections are weaker compared to that of the PC (USA). Welcoming people has a higher rating, but being involved with the community, is lower. The community is not a focus of the congregations of the DRC. The involvement of congregations in their respective communities is in need of improvement.

\section{Looking at development: Four generations of strategic action}

How must we understand, over time, the involvement of congregations in the community or society at large? This 
TABLE 12: Attendee survey: Focusing on the community.

\begin{tabular}{lcc}
\hline Worshippers who ... & \multicolumn{2}{c}{ Average } \\
\cline { 2 - 3 } & DRC & PC (USA) \\
\hline $\begin{array}{l}\text { are involved in social service or advocacy groups } \\
\text { through their congregation }\end{array}$ & 22 & 29 \\
$\begin{array}{l}\text { are involved in social service or advocacy groups in } \\
\text { their community }\end{array}$ & 29 & 38 \\
$\begin{array}{l}\text { contribute to charitable community organisations } \\
\text { report wider community care or social justice }\end{array}$ & 50 & 77 \\
$\begin{array}{l}\text { emphasis as one of the three most valued aspects } \\
\text { of their congregation }\end{array}$ & 27 & 13 \\
$\begin{array}{l}\text { report openness to social diversity as one of three } \\
\text { most valued aspects of their congregation }\end{array}$ & 3 & 8 \\
$\begin{array}{l}\text { worked with others to try to solve a community } \\
\text { problem }\end{array}$ & 16 & 26 \\
\begin{tabular}{l} 
voted in the last presidential election \\
\hline
\end{tabular} & 60 & 81 \\
\hline
\end{tabular}

DRC, Dutch Reformed Church; PC (USA); Presbyterian Church (USA).

Responses are given in percentage. This data was obtained from the attendees survey.

TABLE 13: Attendee survey: Sharing faith.

\begin{tabular}{lcc}
\hline Worshippers who ... & \multicolumn{2}{c}{ Average } \\
\cline { 2 - 3 } & DRC & PC (USA) \\
\hline $\begin{array}{l}\text { are involved in evangelistic activities in the } \\
\text { congregation }\end{array}$ & 8 & 17 \\
$\begin{array}{l}\text { feel at ease talking about their faith and seek } \\
\text { opportunities to do so }\end{array}$ & 12 & 11 \\
$\begin{array}{l}\text { have invited to a worship service a friend or relative } \\
\text { who did not attend in the past year }\end{array}$ & 52 & 48 \\
$\begin{array}{l}\text { report reaching those who do not attend church } \\
\text { as one of the three most valued aspect of their } \\
\text { congregation }\end{array}$ & 13 & 11 \\
\hline
\end{tabular}

DRC, Dutch Reformed Church; PC (USA); Presbyterian Church (USA).

Responses are given in percentage. This data was obtained from the attendees survey.

TABLE 14: Attendee survey: Welcoming new worshippers.

\begin{tabular}{|c|c|c|}
\hline \multirow[t]{2}{*}{ Worshippers who ... } & \multicolumn{2}{|c|}{ Average } \\
\hline & DRC & PC (USA) \\
\hline $\begin{array}{l}\text { have been going to worship services or activities of } \\
\text { this congregation for five years or less }\end{array}$ & 31 & 26 \\
\hline
\end{tabular}

DRC, Dutch Reformed Church; PC (USA); Presbyterian Church (USA).

Responses are given in percentage. This data was obtained from the attendees survey.

TABLE 15: Attendee survey: Outside connections (overall scores).

\begin{tabular}{lcc}
\hline Outside connection ... & \multicolumn{2}{c}{ Average } \\
\cline { 2 - 3 } & DRC & PC (USA) \\
\hline Focusing on the community & 30 & 39 \\
Sharing faith & 21 & 22 \\
Welcoming new worshippers & 31 & 26 \\
\hline
\end{tabular}

DRC, Dutch Reformed Church; PC (USA); Presbyterian Church (USA).

Responses are given in percentage. This data was obtained from the attendees survey.

question leads us to the interpretive task of practical theology: to look for a theoretical interpretation (Osmer 2008:83). The involvement of congregations in the community or society at large may be seen against a wider debate regarding the relationship between development and the role of NGOs. The work of Swart (2006) helps in this regard. Using the initial work of David Korten, he identifies four generations of development action. It is necessary to give a short description thereof (Swart 2006:98-103):

- The first generation focuses on relief and welfare services accompanied by immediate humanitarian action given by welfare service providers. This could include providing individuals and families with food, health care, shelter and education in times of war or natural disaster. The beneficiaries of a first generation strategy are the passive victims of circumstance.

- The second generation have progressed from a welfare approach towards a more developmental one, with community development strategies as focus. These strategies are linked to a project-centred lifespan, and most of the time, they focus on individual communities.

- The third generation's aim is towards the development of sustainable systems. Third-generation strategies look beyond the local community and seek changes in policies and institutions at local, national and even international level, which may constrain local community development. The emphasis is more on influence than control. The critical question is whether a third generation strategy will be enough. In a global world, change and transformation are needed on a wider scale than that of sustainable systems.

- The fourth generation (Swart 2006:132-134) is geared towards a social or people's movement approach to development. This approach is based on the vision of people-centred development. These movements are driven by vision, values and ideas and not by money, budgets and organisational structures. Value and idea-centred processes, directed at the well-being of people and the environment, are the core business as people are the actual subjects of change. A congregation within a missional paradigm will understand this fourth generation strategy. 'The continual conversion of the church happens as the congregation hears, responds to, and obeys the gospel of Jesus Christ in ever new and more comprehensive ways' (Guder 2000:150).

Looking at the four generations, a logical question follows: Where does the community involvement of the congregations of the DRC fit in this model? Most of the work and involvement of the DRC are first- and second-generation strategies. The emphasis is on welfare projects and a large number of the projects are mostly done by the individual members of the congregations. This research shows that the aim is neither the development of sustainable systems (third generation) nor a movement towards a vision of people-centred development (fourth generation). Swart (2006:193) poses the following challenge to a church and its congregations that are only involved in first- and second-generation strategies: 'Clearly, third and fourth generation development action presents the churches with the challenge of new social scientific insights and skills of participating in a new solidarity praxis'. This challenge places a more comprehensive missional conversion or change on the agenda of a congregation.

\section{Congregations, community and change}

As was argued at the beginning of this article, there can be little debate about the fact that congregations in South Africa are situated within a changing environment. The question is: How is one to understand the relationship between congregation, community and change?

\section{According to Ammerman (1999 [see also Table 16]):}

When communities face significant change, congregations that choose to maintain their existing identities may survive for a 
generation or more. Some may actively resist encounters with their new neighbours, but mostly these decisions for continuity are made by default. Eventually, however, most will face a crisis. (p. 106)

As time moves on, congregations will remain untransformed or be part of a new beginning; they will either die or move on. One way or the other, congregations cannot escape change. Congregations in interaction with their community and environment can expect change. Change will take place through the ministry of the congregation, and a congregation '... should expect change as the Spirit works to bring about transformed lives living out of a new nature' (Van Gelder 2007:155).

The changes in a congregation can be described in terms of at least three aspects: resources, structures of authority (the way decisions are taken) and the culture of a congregation (see Ammerman 1999:329-331; also Hendriks 2004).

\section{Resources}

This includes material resources (buildings, finances, etc.), human resources (members, pastors) and relational resources (Hendriks 2004:175). In a changing environment, the availability of resources comes under pressure. Congregations can survive with very few material resources of their own if they have the connections and imagination to find partners and creative uses for the resources they do have. Whilst educated laymen and clergy leaders do not guarantee such imagination, they do help. The DRC is not a growing church; its membership resources are under pressure. Given the historic position of the church, finding new connections and partners might become a challenge.

\section{Structures of authority}

The decision to adapt to a changing environment is the decision of the congregation and its leaders. Legitimacy is earned by means of interaction in the local congregation and is rarely conferred by any outside denominational authority. Denominational support is rarely sufficient. 'Only as the local members decided to take initiative did change actually happen' (Ammerman 1999:331). The decisions must be made by the congregation itself and not primarily by the denomination. The congregation and church council must be brave enough to make important decisions. As seen in the discussion above, currently, the initiative comes more from individual members than from the congregation and its formal structures and strategic processes.

TABLE 16: Direction of the congregation: How would you describe the current direction of the congregation?

\begin{tabular}{lcc}
\hline Direction & \multicolumn{2}{c}{ Years } \\
\cline { 2 - 3 } & $\mathbf{2 0 0 4}$ & $\mathbf{2 0 0 6}$ \\
\hline Dying & 1.2 & 3.4 \\
Busy with maintenance or survival & 45.1 & 48.8 \\
Growing & 43.2 & 42 \\
Dynamically growing & 10.5 & 5.8 \\
\hline
\end{tabular}

Responses are given in percentage. This data forms part of the congregational survey.

\section{Culture}

Each congregation has a unique culture and identity that embodies its understanding of living the Gospel in a certain context (Hendriks 2004:105-106). Ammerman (1999:338342) identifies four ways in which congregations orientate themselves toward their communities:

- Congregations with a civic orientation. These congregations motivate their members to be upstanding and co-operative citizens of the community, helping out where they can. They will not significantly challenge the status quo.

- Activist congregations. Members also want to be upstanding citizens, but they see the goal as requiring advocacy and change. They are more involved and want change in the community.

- Sanctuary congregations seek to shield their members from this world's temptations and prepare them for the world to come. They try to be isolated from the community and its problems.

- The evangelist orientation sees the church as an agent for changing individual lives. Evangelistic orientations are not guarantees of success. They think of evangelism primarily in terms of recruiting people like themselves.

Looking at the DRC, some of the congregations have a civic orientation, but most congregations fall within the evangelistic orientation. Attendees and leaders talk about their faith and invite others to attend a worship service in their congregation. This approach is acceptable within the evangelistic orientation.

Will congregations choose to change in order to adapt to other orientations? Ammerman (1999:345) says that there is a relationship between conflict and change, 'Congregations that systematically avoid conflict are also very likely to avoid changing'. More than half of the congregations in the DRC are busy with maintenance and are trying to uphold their current position (Table 16). They choose not to adapt to a new and changing situation. They choose not to fight nor to change. What will the outcome be? Ammerman (1999) says:

After a period of slow decline, these congregations are likely to disappear from the scene, perhaps making way for utterly different congregations to sprout up in their stead. As with any other ecology, death is an inevitable part of the life cycle. (p. 345)

In the long run, the congregations engaged in maintenance must face the inevitable; this is also true of congregations in the DRC.

\section{Building partnerships between a congregation and its community}

Societies and individuals are increasingly looking towards churches and other faith-based organisations to meet the welfare needs of local communities. (Swart 2009:74). Is there another way to enhance the relationship between congregation and community? Congregations are a part of a community's institutional infrastructure, a part of the structures and connections that make social life possible 
(Ammerman 1999:346). There is, therefore, interdependence between a congregation and its community. We live within networks of mutual trust (partnerships) or social capital. The Sesotho word tsepo for faith and trust is the same, '... applied to the social capital and partnership context, this means that true partners should have faith in each other and experience mutual trust' (Botes \& Abrahams 2008:118). From the perspective of faith and trust, this may help to understand the interaction between a congregation and its community.

A community provides the resources from which people can seek out social support for their basic needs in order to create meaning in and enjoy life (Hendriks 2004:76-79). Social capital is the essential stuff of our lives, the network of skill and trust that makes possible civic live. Social capital is the raw material out of which new organisational species can be created, the residue left when old organisations die (Ammerman 1999:347). Social capital can be viewed as the social resources that people need for their individual livelihoods. In the absence of other assets, poor people rely for their survival on their relationships, associations and networks. Without sufficient social capital, individuals can become marginalised or vulnerable (Botes \& Abrahams 2008:118). The value of congregations as a provider of social capital cannot be underestimated. Congregations are amongst the most effective generators of social capital, in other words, those connections of communication and trust that make possible the organisation of a complex society (Ammerman 1999:362). Trust is an important component in the foundation and building processes of congregations.

Botes and Abrahams (2008:119) make the important point that faith-based organisations, churches and congregations have a comparative advantage over other institutions in that they have considerable levels of trust invested in them and in the manner in which they inspire activities of voluntary outreach. Churches (and congregations) could play an important role in partnership-building in communities. In South Africa, the legacy of apartheid eroded the levels of trust between groups and institutions, thereby eroding social capital. 'Participation, co-operation, sharing and community development through networks, then, become a key challenge for the true community church' (Swart 2004:337). This is a challenge, especially in the case of the DRC, given its history and position within the South African society. There is a need to turn this around.

Networks and partnerships are agreements made for the mutual benefit of congregations and their community. The relationship between God and believers are described in partnership terms: body, covenant and contract (Botes \& Abrahams 2008:123). Building partnerships, therefore, need not be a foreign concept and process for congregations. 'True partnership-building implies a new way of structuring relationships, of going beyond mere co-operation between stakeholders in ways to avoid co-option and domination' (Botes \& Abrahams 2008:131). The aim of partnerships is the creation of mutually beneficial relationships and building networks of trust for a joint cause and also for each other.
Partnerships will help congregations to move away from first and second-generation strategies of development towards third and fourth-generation strategies.

Congregations provide identification with a community and a sense of belonging to a society. Partnerships can be utilised to unlock the social capital within congregations so that they become involved in communities (see Ammerman 1999:362; Swart 2004:337). Trust, social capital and partnership building may help congregations in another and new way to be involved in the community.

\section{Conclusion}

At the beginning of this article, the following critical questions were posed: Do churches and congregations make a difference in society? Or to be more specific: Do the DRC and its congregations make a difference in the South African society?

The Christian church is the most representative institution or non-governmental organisation (NGO) in civil society in South Africa (Krige 2007:2). In the South African context, churches and especially congregations can make an enormous contribution towards the community and its well-being. Congregations represent the moral order of the community and the best human values (Ammerman 1999:368). The community needs congregations for moral and spiritual capital. There is a need to rediscover a socioecclesial analysis (Kumalo \& Dziva 2008:184). In working together or challenging one another, church and State require a rigorous process of analysis so that the reasons for co-operation or resistance can be clearly seen. After the struggle against apartheid, South Africa experienced a loss in leadership, and it left a large vacuum (De Gruchy \& Ellis 2008:14). There is a need for a kind of leadership in 'another country', to set a new agenda for development (De Gruchy \& Ellis 2008:18-19). The need is for the church to reposition itself in a new context. Ammerman (1999) says:

Congregations are both sacred places, making claims for the power of a transcendent Other in the midst of this world, and civic places, mobilising all sorts of resources for the sake of the community. (p. 370)

We can, therefore, say affirmatively in answer to the question posed earlier that churches and congregations can make a difference in society. The South African context, as has been pointed out, poses a new challenge to the church and congregations.

What can we conclude with regard to the DRC and its relationship with the community? Within the congregations and amongst the leadership of the DRC, there is a movement towards less involvement in society. The involvement of DRC congregations is mostly on the level of welfare projects (first and second generation) and within an evangelist approach. The challenge for congregations in South Africa and, in the context of this article, for the DRC is a movement towards building partnerships of trust within the community for the purpose of sustainable people development. August and 
Wyngaard (2004) state:

The local church today is unique in its fight against poverty alleviation in that it engages in holistic human development that includes the spiritual formation of people through the preaching of the Good News and the life-changing power of the Holy Spirit. (p. 465)

This needs to be true of every congregation in its encounter with the community, whatever their challenge may be.

\section{Acknowledgements Competing interests}

The author declares that he has no financial or personal relationship(s) which may have inappropriately influenced him in writing this paper.

\section{References}

Ammerman, N.T., 1999, Congregation and community, Rutgers University Press, London.

August, K. \& Wyngaard, J.G., 2004, 'Congregations in communion with the poor', NGTT 45(2), suppl. ser.

Bosch, D.J., 1991, Transforming mission: Paradigm shifts in theology of mission, Orbis Books, New York.

Botes, L. \& Abrahams, D., 2008, 'Noka e Tlatswa ke Dinokana - A river swell from little streams: Responsive partnership-building approaches to development', in S. De Gruchy, N. Koopman \& S. Strijbos (eds.), From our side: Emerging perspectives on Gruchy, N. Koopman \& S. Strijbos (eds.), , From our side: Emerging
development and ethics, pp. 117-134, UNISA Press, South Africa.

De Gruchy, S. \& Ellis, W., 2008, 'Christian leadership in 'another country': Contributing to an ethical development agenda in South Africa today', in S. De Gruchy, N. Koopman \& S. Strijbos (eds.), From our side: Emerging perspectives on development and ethics, pp. 9-20, UNISA Press, South Africa.
Dinokeng scenarios: 3 futures for South Africa, n.d., Dinokeng scenarios, viewed 15 February 2011, from http://www.dinokengscenarios.co.za/

Durand, J., 2002, Ontluisterende wêreld: Die Afrikaner en sy kerk in 'n veranderende wêreld, Lux Verbi BM, Wellington.

Erasmus, J.C., 2009, 'Double legacy: Perceptions of churches as welfare agents in the new South Africa', Journal of Theology for Southern Africa 133, 41-58.

Erasmus, J.C., Louw, A. \& Van der Merwe, W., 2009, 'Changing landscapes of welfare, religion and gender: The impact on the role of the churches', Journal of Theology for Southern Africa 133, 8-25.

Friedman, T.L., 2006, The world is flat: The globalized world in the twenty-first century, Penguin Books, London.

Guder, D.L., 2000, The continuing conversion of the church, William B. Eerdmans Publishing Company, Grand Rapids, MI.

Hendriks, H.J., 2004, Studying congregations in Africa, Lux Verbi BM, Wellington.

Hendriks, H.J., 2007, 'Missional theology and social development, HTS Teologiese Studies/Theological Studies 63(3), 999-1016.

Krige, S., 2007, 'The quest for a faith-based development approach in an African city context based on the Tshwane leadership foundation experience', Unpublished mini-dissertation in partial fulfilment of an M.A. in Development Studies, University of the Free State, Bloemfontein.

Kritzinger, J.J., 1994, 'The Dutch Reformed Church (NG Kerk) and Development: Three Models', Journal of Theology for Southern Africa 87, 49-61.

Kumalo, S.R. \& Dziva, D., 2008, 'Paying the price for democracy: The contribution of the Church in the development of good governance in South Africa', in S. De Gruchy, N. Koopman \& S. Strijbos (eds.), From our side: Emerging perspectives on development and ethics, pp. 171-188, UNISA Press, South Africa.

Osmer, R.R., 2008, Practical Theology: An Introduction, William B. Eerdmans Publishing Company, Grand Rapids.

Swart, I., 2004, 'Community-centred congregational ministry in South Africa: a plea for renewal', NGTT 45(2), suppl. ser.

Swart, I., 2006, The churches and the development debate: Perspectives on a fourth generation approach, Sun Media, Stellenbosch.

Swart, I., 2009, 'Meeting the rising expectations? On local churches as organisations of social welfare in South Africa', Journal of Theology for Southern Africa 133, 74-96.

Van Gelder, C., 2007, The ministry of the missional church, Baker Books, Grand Rapids.

Woolever C. \& Bruce D., 2004, Beyond the ordinary: Ten strengths of U.S congregations, Westminster John Knox Press, Louisville. 